US Army Corps

of Engineers

Waterways Experiment

Station

\title{
Periodic Inspections of Kahului and Laupahoehoe Breakwaters, Hawaii
}

\section{Report 1 \\ Base Conditions}

\author{
by Dennis G. Markle, WES \\ Stanley J. Boc, Pacific Ocean Division
}

Approved For Public Release; Distribution Is Unlimited

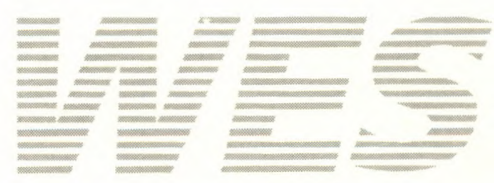

Prepared for Headquarters, U.S. Army Corps of Engineers 